\title{
Education and Freedom*
}

\author{
By Dr. A. W. Pickard-Cambridge
}

$\mathrm{N}^{\circ}$ one with any power of discernment can have failed to note two opposite tendencies at work in the present day: one, a tendency antagonistic, both in intention and in fact, to freedom; the other, a tendency to lay claim to freedom in ways which it is not always possible to defend. The second of these tendencies is seen in a number of educational theories which would, so far as possible, exclude discipline from life in the supposed interests of free development; and also in a certain impatience with all forms of authority, of which those who are associated with young people have been more conscious in recent years than, for example, before the War. But the other tendency we can see writ large on the recent history and present condition of nations and also reflected in the smaller letters of individual mentalities. In Germany, Italy and Russia we are watching the complete subordination of the individual to the State, not only in his external life and action, but also, so far as education and propaganda can achieve it, in thought and will.

If such phenomena were only presented to us by foreign peoples, they would even then merit our very serious attention; but he would be very blind who did not see the same tendency at work among ourselves. We call ourselves a democracy, and the essence of democracy is that it rests upon the free expression of individual thought; but the rigidity of organisation in our political parties has increased during the present century to an ominous degree, and with it the application of what is called 'party discipline', depriving the individual of all freedom of action and speech, what. ever freedom of thought he may privately retain. It is at least equally serious, that some of the constructors of the imaginary Utopias which have been most popular with the younger generation in the last few years clearly envisage and apparently approve of political and educational systems based upon the complete elimination of individuality.

Now if this view is accepted, if it is definitely decided that freedom is not worth keeping, the consequences in the field of education will obviously be accepted also-the strict control of all that is to be taught, and of the method of teaching it; the exercise of thorough-going

* From the presidential address to Section L (Educational Science) of the British Association delivered at Norwich on September 6. espionage upon teachers and pupils, and the encouragement in both ranks of the giving of information against colleagues and companions; the supervision of every part of the individual life, so that there may be no loophole anywhere for the intrusion of counter-influences, and no opportunity for the expression of free thought. There may be those who feel that such a state is what ought to be ; and I do not now propose to argue with them; but what $I$ have to say is based upon the opposite assumption, that individual freedom, subject to such a minimum of restriction and organisation as is necessary for life as a member of a community, is the indispensable condition of a good and even a tolerable human existence, and that just as the educational systems of coercive States, real or imaginary, are directed to the maintenance of the systems of government and life which have given rise to them, so the educational system of a democratic State, which is based on the principle of freedom, should be directed towards the maintenance of that freedom, and the encouragement of its responsible use. As the principle of the direction of education in accordance with the 'spirit of the State' must necessarily result, in the authoritarian State, in training citizens not to think, so education in the spirit of a polity of free men and women must above all train them to think freely and accurately, and to desire to carry the results of their thinking into action. As the former type of State will try to produce a standardised and unresisting mentality, the latter will allow the utmost variety and will look for the good life of the community to the clash in rational discussion of the most diverse views, brought to judgment before the bar of a public opinion in the formation of which all alike may take their part.

The ideal State and community will be a democraoy in which every individual is free to realise the highest values, physical, moral and spiritual ; and the realisation of some of these is only possible if he can enter into freely determined mutual relations with others, participating fully in the life of the community, communicating his share of good to it, receiving his share of good from it. The community and the State will recognise fully the value of the individual personality, and will acquiesce in no condition which makes any individual merely a means to the wellbeing of others, or to the stability of the organised 
community, for the sake of which in authoritarian States, real or Utopian, individuality is sternly suppressed.

But the desired freedom of the individual has to encounter obstacles of more than one kind, and it is in a great measure with these that education has to deal. The obstacles are partly in himself, partly in the community. It is obvious at once that no one, as he is, is completely free. Everyone is greatly hampered by the effects of heredity, which, whatever the mechanism, seem to be mental as well as physical ; by the influence of body upon mind; by the tendencies imparted by early environment and habituation; and by the results of his own actions. Yet it is probably a fair summary of what may be inferred from common experience, that each individual has at any moment a certain balance or reserve of freedom, that is, of power to act in the way which he recognises to be good-a balance or reserve which he can increase or diminish by every individual act, every exercise of will, so far as he $i s$ free. Therein lies (as all moralists have seen) the importance of each single action; for it is in the determination of single actions that increased freedom must be won. By constant action in one direction, habits are formed which it is very difficult to break. By repeated choice of the higher as against the lower values, the choice of these becomes easier ; freedom is increased. Accordingly, one purpose at least of education is to set what seem to be the higher values before the immature mind in such forms as it can understand, and to encourage the habit of choosing them. About most of these higher values there is really very little doubt, and in such forms as kindness, unselfishness, truthfulness, fair-play, thoroughness, neatness and other elementary kinds of beauty, they are as accessible to young minds as to old.

Further, the importance of discipline depends upon the fact that without it-without a certain external compulsion at times-the immature personality may not discover that it has the freedom to choose something other (and, as it will afterwards recognise, something better) than that which immediately appeals to it. Discipline, correction and guidance reveal the power of choiceof doing what you do not want to do ; and in time self-discipline follows and freedom increases in proportion-freedom, that is, to pursue and realise ends or values deliberately chosen, because they are recognised as good. No one can possibly be less free than one who has always been allowed to do what he likes; he will never have discovered that he can do anything else. To deprive the young in the name, forsooth, of freedom, of all benefit from the experience of earlier generations-to put no values before them as good-is not, in fact, to increase, but to restrict their freedom by denying them the conditions of a fair choice. The young mind has neither the information nor the training to decide everything for itself. But it is the object of education and of discipline that it may ultimately have these, and may do some things, no longer because they are imposed by authority, but because they are recognised to be good, and other things, it may be, because the ideas suggested by authority have now been revised and modified by the growing reason. If the discipline and guidance are accompanied, so soon and so far as is possible, by reasons which will not only suggest why it is that such and such acts and habits are good and so cause the discipline to be willingly accepted, but will, above all, help to form the habit of reasoning and of considering what is good or bad, the result, so far from hampering freedom, will be to elicit and enhance it.

It is clear that over and above the influence of wise suggestion and example, not only in the general life of the school as a society, but also in the choice of literature, in the study of characters both in literature and history, and in the presentation, in however simple a form, of the working in history of cause and effect, an immense opportunity is open to the teacher.

But education has much more to do in the cause of freedom than the encouragement of a habit of discriminating between good and evil, or better and worse, and the suggestion of the lines of such discrimination. For before life is far advanced, the simple problems and issues of early days are merged in far more complicated issues, requiring the utmost clarity of thinking; and not only does the true discrimination between values itself become more difficult, but also a knowledge of facts, a power of analysing them and appreciat. ing their bearing, and therewith an understanding of the particular conditions in which the realisation of ideals of good has to be attempted, become essential ; in short, a clearness of perception and judgment without which the best intentions may end in disaster.

For effective thinking two conditions are necessary : first, that the materials with which thought has to deal shall be so far as possible true, or, in other words, that truth about facts shall be accessible; secondly, that the mind itself shall have been trained to work accurately and honestly ; and if freedom in political and private life is to be preserved, those who educate others must put them in the way of obtaining truth about facts and of distinguishing truth from falsehood in what is presented to them and in their own reasoning. It would take a very brave man to deny the immensity of the obstacles. Even in a country so free as our own, the temptations to accept opinion 
manufactured by others, not always for the best ends, are enormous.

Yet preparatory work may be done on the lines which are followed, at least in a few schools, in which in some upper forms present-day problems are discussed, or the news of the week presented, in ways which encourage older boys and girls at least to think about them, to be aware of the two or more sides that each question presents, to realise the duty which lies upon them, or will shortly lie upon them as citizens, to get the best information and to form their opinion with a high sense of responsibility and a disregard of the interest of class or self. They can be led to realise that democracy is less a system of equal rights than a system of equal responsibilities; and even the common life of the school can teach them how much one clear and decided mind can do in shaping the opinion of its own circle. The foundation of habits of impartial and critical judgment can be laid at school, and if they are not laid there, the odds are heavily against their being laid anywhere else. The teaching of history is an obvious instance of the opportunity which education affords for the formation of habits of careful judgment. As in all other matters, there must be an impartial presentation of facts and issues, and, if possible, opportunity of discussion of a kind suited to the age of the pupils.

In other ways, the dangers of dependent, unventuresome and even servile mentality may be partly met by the school. Young people are much more likely to think for themselves, if, subject to the necessary framework of school discipline which is scarcely felt so long as it is wisely controlled, they do things for themselves. This is well understood in the older public schools, but I confess that in a great number of secondary schools-and secondary schools are of special importance, because from them should come the leaders of opinion in nearly all those smaller circles in which, much more than on platforms, public opinion is made, as well as most of the future teachers of the mass of the people-I should like to see a good deal more room for independence and self-government. It is impossible to train young people in the free use of judgment without letting them exercise it freely in their own affairs and (with slight and obvious limitations) make their own mistakes, and grow in the power of judging how to act and of understanding the characters one of another; for in a free State, the power to choose persons is as important as the power to choose between policies, and there is no place so good as a school for learning either to lead or to choose and follow a leader.

Again, no one can deny the effect of the mechanised drama, which is the almost universal recreation on certain days in the week, in producing a standard mentality (one might almost say a uniformity of bad taste) and in confining interest to monotonously narrow lines; and the fact that the interest in sport of which our countrymen boast takes, for nine-tenths of them, the form not of healthy personal activity but of massed attendance at the performances, provided for them by no effort of their own, of two teams of hired entertainers or of a few trained dogs, is not indicative or productive of an active intelligence. If education is to counter this, it must encourage those occupations of leisure in which the individual can exercise his own free choice and express himselfthe performance (not merely the hearing) of music and drama, the practice of handicrafts, of arts, of gardening, of all kinds of performances which are personal, not mechanical. It must set before the young the infinitely various ways of spending time worthily; and must encourage an attitude towards books and reading which few of our examination-ridden youth attain. For all these things are the activities of free minds, not of those which accept unthinkingly everything which is superficially attractive and is therefore accepted by crowds. Without some such influence from education, we can expect only passive minds, barren of ideas, and unable to rise by freedom of thinking to meet the perpetually changing needs of the world in which they are called upon to live.

As I have spoken of examinations, I had better say explicitly that I rank examinations, not in themselves, but as they are treated in most schools at the present time, among the worst enemies to education in freedom of thought and independence of judgment. Examinations can be, and should be, invaluable aids to education; but it is a condition of this that they should be only an incident in the work of the school, testing at convenient points the work of both teachers and pupils, and really, and not merely by profession, following and not directing the curriculum. Their usefulness is undoubted in training the young mind to do what it will continually have to do afterwards-namely, to bring whatever knowledge and resource it may have to bear on a particular point at a given moment, and in this both intellectual and moral qualities are involved. But where the whole work of the school is planned to cover or lead up to the syllabus of some particular examination; where every subject is studied at a rush in order to work into the pupils' minds what are virtually prescribed answers to questions which may almost be said to be prescribed, so narrow is the range from which they can be drawn; where the teacher does not dare to encourage his pupils to think; where he cannot go at his own pace and cover in his own way the ground which he can effectively cover, for 
fear of the effect on the statistics by which the local education authority, knowing little of education, judges the efficiency of his school and his own fitness for promotion, or by which the employer, knowing even less, judges the suitability of individuals for purposes never contemplated by the examination authorities--there examinations are a very mischievous thing. Unless the habit of working and teaching for examinations before everything else is abjured, I see little hope of the type of education which alone can save democracy, and bring up a race of free men and women.

There are other reforms which are urgently needed, if our present system of education is to be brought nearer to the fulfilment of such an end. The prolonging of the time of education is obviously one, provided that the education is of the type which liberates and trains the mind, and does not merely rivet its fetters more tightly. A great reduction in the size of classes in most subjects is another; not necessarily in all subjects, or for all purposes; but such a reduction as will give the individual member of the class a chance, and will enable a teacher to encourage a pupil who has a line of his own to follow it up, and to see that every pupil is mentally active and not merely receptive. Young people have not indeed enough experience to prescribe or to conduct their own studies to the extent imagined by some enthusiasts; but they have minds which should not be allowed to be inert or be driven along precisely the same route as twenty-nine or thirty-nine other minds, and the smaller the class the less the risk of this.
The suggestions which I have made as regards educational practice have nothing new in them, but I have deliberately chosen familiar instances to illustrate my main contention. My object has been to assert that these are no matters merely of theory or of finance or of administrative or political convenience, but of vital and immediate urgency, if we are not unconsciously to bring up a race which, with its mind stunted, its capacity for freedom undeveloped, will be the easy prey of the politician, the journalist and the dictator; and that if a free democracy is to continue, we must educate for it, for in many respects our present educational system is better calculated to produce a servile and passive mentality than to elicit an activity of mind and an independence worthy of free men and women.

We have reached a point in the history of Western civilisation when the forces which make for the enslavement or the inertness of mind and spirit are active as they have not been for centuries. It is therefore incumbent upon us to test our educational institutions and methods at every point by their tendency to produce or to hinder freedom of mind, to cut out all that makes for the standardisation of individualities or is hostile to ultimate independence of judgment, at the same time so setting before the young the higher values, which make for good life and good citizenship, that they may have the chance of freely making them their own. If we can do this, we may yet see the development of a type of humanity richer in freedom, self-discipline, courage and vision than any which the world has yet known.

\section{Recent Progress in the Study of Early Man*}

\section{By Sir Arthur Smith Woodward, F.R.S.}

$\mathrm{W}^{\mathrm{n}}$ HEN meeting in East Anglia it is appropriate that the Section of Anthropology should devote special attention to prehistoric archæology. In this part of England so long ago as 1797, John Frere made the first scientific observations on palæolithic implements which he had dug out of a superficial deposit at Hoxne. During recent years, Mr. J. Reid Moir has excited wide interest by his discoveries of the oldest known stone implements, which he has collected with remarkable zeal and discussed with acute observation. Here also arose the 'Prehistoric Society of East Anglia', which has been so well supported

* From the presidential address to Section $\mathrm{H}$ (Anthropology) of the British Association delivered at Norwich on September 9. during its career of more than twenty years, that it has gradually widened its sphere until now it becomes the 'Prehistoric Society', devoted to advances in its subject in all parts of the world. We are, indeed, now confronted with problems much greater than those which the pioneers in western Europe dealt with, when they were laying the foundations of research in prehistory. Traces of men who lived before the dawn of history in widely separated parts of the earth's surface have been discovered in increasing abundance during recent years ; and a study which at first was more or less local has now become one of world-wide scope.

Among the several branches of science which contribute to our understanding of the subject, 